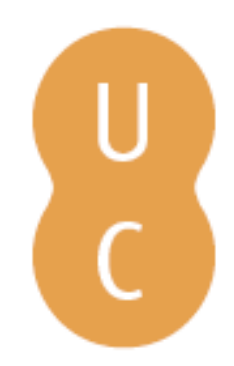

\title{
pommalina
}

\section{Fundamentos evolutivos e culturais da ciência da informação}

Autor(es): $\quad$ Marcondes, Carlos Henrique

Publicado por: Imprensa da Universidade de Coimbra

URL

persistente: URI:http://hdl.handle.net/10316.2/31853

DOI: $\quad$ DOI:http://dx.doi.org/10.14195/978-989-26-0319-3_5

Accessed : $\quad$ 26-Apr-2023 11:08:42

A navegação consulta e descarregamento dos títulos inseridos nas Bibliotecas Digitais UC Digitalis, UC Pombalina e UC Impactum, pressupõem a aceitação plena e sem reservas dos Termos e Condições de Uso destas Bibliotecas Digitais, disponíveis em https://digitalis.uc.pt/pt-pt/termos.

Conforme exposto nos referidos Termos e Condições de Uso, o descarregamento de títulos de acesso restrito requer uma licença válida de autorização devendo o utilizador aceder ao(s) documento(s) a partir de um endereço de IP da instituição detentora da supramencionada licença.

Ao utilizador é apenas permitido o descarregamento para uso pessoal, pelo que o emprego do(s) título(s) descarregado(s) para outro fim, designadamente comercial, carece de autorização do respetivo autor ou editor da obra.

Na medida em que todas as obras da UC Digitalis se encontram protegidas pelo Código do Direito de Autor e Direitos Conexos e demais legislação aplicável, toda a cópia, parcial ou total, deste documento, nos casos em que é legalmente admitida, deverá conter ou fazer-se acompanhar por este aviso.

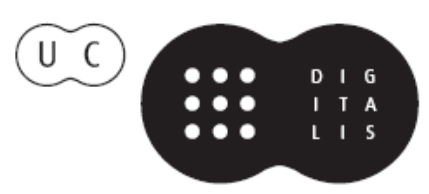


Maria Manuel Borges

Elias Sanz Casado

Coordenação

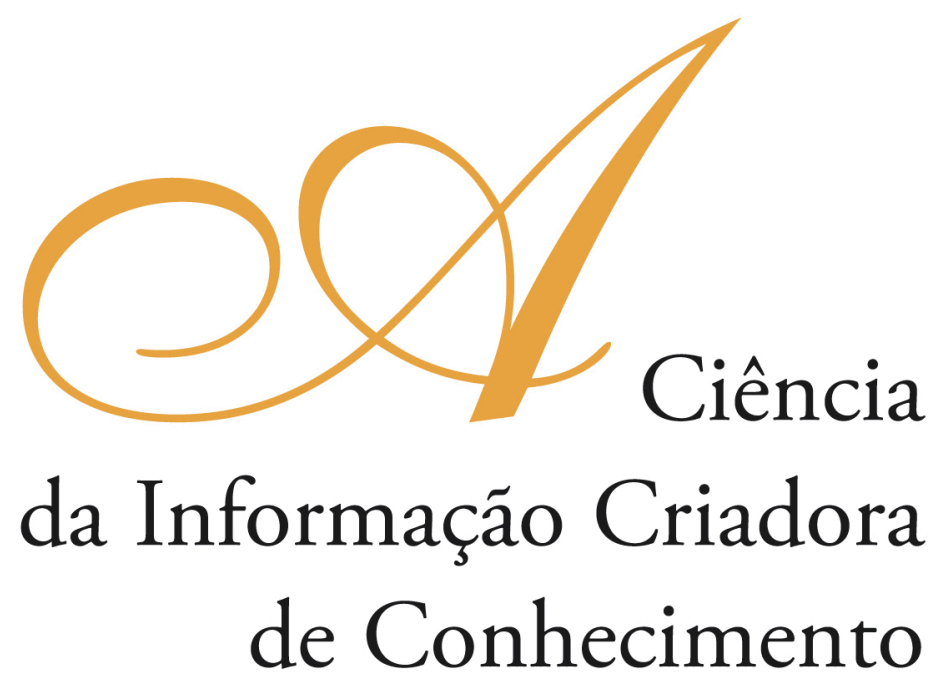

Vol. I

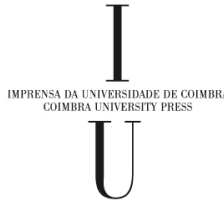

- COIMBRA 2009 


\title{
Fundamentos eVolutivos e CULTURAis \\ da CiênCia da Informação
}

\author{
Carlos Henrique Marcondes \\ Universidade Federal Fluminense (Brasil)
}

\section{Resumo}

São propostas bases antropológicas, evolutivas, culturais e sociais como fundamentos para a Ciência da Informação, a partir de uma discussão sobre o papel central desempenhado pela linguagem no desenvolvimento da cultura e na configuraçáo das sociedades humanas. É discutido seu papel como mecanismo cooperação e articulação social que garante à espécie humana um diferencial evolutivo decisivo. Este papel da linguagem é mantido e ampliado através da invenção de documentos, viabilizando que as sociedades humanas ampliassem sua complexidade.

\begin{abstract}
Anthropological, evolutionary, cultural and social bases are proposed to Information Science, from a perspective which discusses the central role of language in the development of culture and in the shaping of human societies. The role of language as a social coordination and cooperation mechanism is discussed, one which has provided an evolutionary differential to mankind. This essential role of language is developed and amplified through the invention of documents thus enabling human societies to evolve into more and more complex systems.
\end{abstract}

\section{Introdução}

Informação é um conceito de ampla abrangência, a ponto de ser mesmo identificado como uma das entidades fundamentais da realidade, junto com a matéria e energia. É também de interesse de diversas áreas de conhecimento, desde a Biologia, Matemática, Computação, Comunicação, Psicologia, Educação, Administração, etc. Além disso, na atualidade, pelo fato de estarmos vivendo na assim chamada "Sociedade da Informação", o conceito de informação vêm sendo utilizando de maneira tão livre e sem rigor científico pela mídia em geral, que tem resultado numa grande confusão conceitual.

A área de conhecimento da Ciência da Informação tem se ressentido desses problemas. Esta falta de rigor definitório e conceitual consensual tem inclusive contaminado muito do discurso que se reivindica da Ciência da Informação. Definiçóes iniciais da área como as cunhadas no evento considerado fundador da disciplina, no Geórgia Institute of Technology no início da década de 60 do século XX, são pouco rigorosas e muita vezes, praticamente circulares, uma vez que não definem o que seja informação. Ciência da Informação seria portanto: "Ciência que investiga as propriedades e comportamento da informaçáo, as forças que governam o fluxo de informaçáo e os 
meios de processamento da informação para otimização da acessibilidade e do uso." ${ }^{1}$ (Shera \& Cleveland, 1997, p. 265).

Pioneiros da Ciência da Informação na década de 60 a conceituavam como uma disciplina voltada para problemas, em especial o assim chamado problema da "explosão informacional", que caracterizaria a sociedade que se delineava no pós 2a . Guerra Mundial em oposição às sociedades anteriores.

Esta ênfase operacional da Ciência da Informação em seus primórdios, se por um lado deixou lacunas e contribuiu para uma grande confusão conceitual da qual a Ciência da Informação se ressente até hoje, pelo lado econômico da assim chamada "indústria da informação", se constituiu num sucesso, dando origem a um dos setores econômicos mais dinâmicos da sociedade atual. Esse forte setor econômico da "indústria da informação" contribuiu pelo seu peso social, pelas suas ligaçóes com a mídia, pelos fortes interesses econômicos mobilizados, para cristalizar conceitos e terminologias para o fenômeno informação - num processo chamado por Freitas (2003) de "invençâo da informação" - destituídos do necessário rigor requerido por uma disciplina científica.

A principal confusão introduzida pelo uso coloquial e a-científico do termo pela mídia é denominar informação tanto toda a parafernália de registros ou objetos com potencial informativo disponíveis nas redes eletrônicas na sociedade atual quanto o processo humano de informar ou informar-se propriamente dito. Diz-se que registros com potencial informativo, como os existentes numa base de dados na Web ou disponíveis através de um mecanismo de busca como o Google, são "informação".

A maneira de lidar com esta situaçáo é, sem esquecer a riqueza e o potencial dados pela generalidade e transversalidade do conceito por diversas áreas de conhecimento e procurando manter para a Ciência da Informação uma compatibilidade com este escopo mais abrangente, procurar delimitar claramente um conceito de informaçáo de interesse da Ciência da Informaçáo. Isso vem sendo feito por vários autores ao longo da discussão epistemológica da Ciência da Informação.

Autores têm buscado, acertadamente, bases conceituais para a área a partir de uma definição de informação (Belkin \& Robertson, 1976, (Buckland, 1991), (Bates, 2005). O recente artigo de Zins (2006) coloca no entanto para a Ciência da Informação um situação desanimadora. A multiplicidade de formulaçóes para conceitos fundamentais para a área como dados, informação e conhecimento, se torna um sério obstáculo para o ensino, a pesquisa e o planejamento/gestáo de sistemas de informação. A par de continuar na busca de delimitação do escopo e abrangência da Ciência da Informação, um movimento que buscasse bases outras que as simplesmente orientadas a problemas, como tem sido uma prática comum, ou entáo epistemológicas - lógicas, definitórias ou classificatórias -, bases que pudessem alcançar um grau maior de consenso, poderia contribuir para dar maior consistência e fundamentar a Ciência da Informação.

Nenhum pesquisador sério hoje questionaria a Teoria da Evolução de Darwin ou a Teoria da Relatividade de Einstein. As evidências da validade dessas teorias têm se acumulado desde a sua formulação. Grandes consensos científicos podem fornecer bases mais sólidas para a Ciência da Informação. O objetivo deste trabalho é portanto

\footnotetext{
1 Tradução nossa.
} 
buscar e propor bases antropológicas, evolutivas, sociais e culturais como fundamentos para a Ciência da Informação. Recentes descobertas da Psicologia Evolutiva, da Antropologia Social, da Biologia Evolutiva, principalmente, têm iluminado questóes relativas à evoluçáo humana, o papel nesta do social, da cultura e da linguagem. Se conseguirmos seguir uma linha evolutiva pelas questóes colocadas por estas disciplinas até encontrarmos os atores, objetos, processos e relaçóes de interesse para a Ciência da Informação, teremos contribuído para alicerçar nossa disciplina em bases mais sólidas e com mais potencial de consenso.

Apesar de reconhecimentos esparsos ao longo da sua história do débito da Ciência da Informação com a Documentação, a discussão do documento dentro da CI foi, de uma certa forma, ofuscada e mesmo considerada ultrapassada frente a um objeto que parece ter um apelo muito maior, a informação (Freitas, 2003). A recente revalorização das discussóes sobre o documento na CI - Lund (2009, p. 399) fala de "a renaissance for the document approach" - mostra como muita elaboração teórica ainda é necessária para compatibilizar e integrar a questão do documento no escopo teórico da CI. É necessário avançar na construção de uma consistente ontologia do documento, não somente no sentido do que ele é hoje, mas dos processos que permitiram ele vir a ser o que é.

A tese aqui proposta é que mecanismos para enfrentar a chamada "explosão informacional" que caracterizaria a sociedade atual, aparentemente um fenômeno táo contemporâneo, tem raízes nos mecanismos de articulação social que remontam às sociedades humanas mais primitivas. A evolução histórica da sociedade humana para formas cada vez mais complexas, ao ser um imperativo evolutivo e de sobrevivência da própria espécie humana, demanda pari passo mecanismos de articulação social cada vez mais complexos que são providos num primeiro momento pela linguagem e, posteriormente, por documentos.

A metodologia utilizada foi a análise retrospectiva a partir de aspectos antropológicos e evolutivos da humanidade e do papel da linguagem e cultura nestes processos. Cognição, cultura e linguagem são noçôes fundamentais para uma discussão sobre os fundamentos da CI. A partir de visóes recentes da Antropologia Cultural, Biologia Evolutiva e Psicologia Evolutiva são percorridas questôes como a emergência do pensamento simbólico, o surgimento da cultura, da linguagem, da escrita, para culminar no documento. Autores como Tatterasall, discutindo o surgimento da cogniçáo moderna, Nowak \& Komarova (2001), discutindo o surgimento da linguagem, Dunbar (1993) e Knight et al (2000), discutindo o papel social da linguagem, Maturana \& Varela (2000), discutindo os fundamentos biológicos da cognição humana, lançam novas luzes para compreensão do papel dessas questôes na evolução humana. Dessas discussóes também emerge a noção de articulação e cooperação social, essencial para a linha de argumentação aqui desenvolvida. Também aportes de teorias meta-disciplinares como a Teoria Geral dos Sistemas e a Semiótica são buscadas para a compreensão dos processos informativos.

\section{Evolução humana, linguagem e cultura}

O homem enquanto ser biológico, seguindo uma trajetória que remota aos grandes antropóides, têm sua sobrevivência individual e sua evolução enquanto espécie, 
irremediavelmente ligadas a sua organização social. Maturana \& Varela (2001, p. 217) chamam de fenômenos sociais "a participação de organismos na constituição de unidades de terceira ordem". Para os autores, unidades de terceira ordem seriam agrupamentos sociais formados pela articulaçáo de indivíduos, organismos multicelulares dotados de sistema nervoso (unidades de segunda ordem). Esta participação tem um caráter específico e fundamental para a vida desses organismos: “... os organismos participantes satisfazem suas ontolgenias individuais principalmente pelo acoplamento mútuo, na rede de interaçóes recíprocas que formam ao constituir as unidades de terceira ordem".

No homem, mais que em qualquer outra espécie, o social tem um peso evolutivo decisivo. Mais do que buscar causas ou seqüências que a própria Antropologia não consegue estabelecer com precisão, observa-se na espécie humana características que foram se firmando ao longo da evolução, que vinculam esta evoluçáo ao social. O homem não é excepcionalmente forte ou rápido em comparação aos predadores e a caça; macho e fêmea são unidos por uma sexualidade permanente e não sazonal; a maturação do bebê humano é lenta quando comparada a outras espécies; pai e mãe e o restante do grupo têm que colaborar na busca de alimento, na criaçáo e proteção dos filhos; a postura bípede que se firmou na espécie humana permitia mãos livres para carregar alimento até o grupo, desobrigando o homem de levá-lo imediatamente à boca. A alimentação que passava a incluir crescentemente carne permitiu um aumento do volume cerebral.

Este conjunto de características vai se firmando ao longo da evolução humana de tal forma que o social adquire um caráter estrutural. De um ponto de vista evolutivo, dentro dos mecanismos de interação social humanos, certamente a linguagem (Vygotsky, 2001) tem um caráter determinante. Nowak \& Komarova (2001) destacam este aspecto:

Language allowed our ancestors to share ideas and experiences, and to solve problems in parallel. The adaptive significance of human language is obvious. It pays to talk. Cooperation in hunting, making plans, coordinating activities, task sharing, social bonding, manipulation and deception all benefit from an increase in expressive power. Natural selection (we use it to include sexual selection) can certainly see the consequences of communication.

Do ponto de vista funcional-genético as habilidades lingüísticas dependem de um gene denominado FOXP2 (Enard et. al (2002). Estes autores apresentam um estudo comparado do FOXP2 em macacos, antropóides e no homem. As habilidades lingüísticas humanas envolveriam um controle sofisticado de órgãos como a laringe e a boca, não estão presentes no chimpanzé, que são viabilizadas por este gene. Os estudos de Enard apontam que esta característica fixou-se na espécie humana há cerca de 100.000 anos, o que é compatível com as descobertas relatadas por Wong relativas a vestígios da emergência do pensamento simbólico na forma de adornos e desenhos em objetos de pedra datados de período semelhantes e encontrados num sítio arqueológico da África do Sul.

Animais em geral e antropóides em especial comunicam-se para articularem seus comportamentos individuais. Para isso utilizam diferentes sinais, gestos e sons. Karl Bühler (1990, p. 34) vê na linguagem humana um sistema de comunicação entre 
indivíduos e identifica nela três funções semânticas: expressiva, apelativa e descritiva. Algo semelhante à função apelativa de Bühler pode ser encontrada em diferentes animais. Karl Popper (1997) afirma que as duas primeiras destas funções são características também dos animais, conforme exemplifica Vygotsky (2001, p. 9), ao discutir as especificidades da linguagem humana em relação aos sistemas comunicativos dos animais: "O ganso atemorizado que de súbito se apercebe dum perigo e alerta todo o bando com os seus gritos não está dizendo aos restantes o que viu, antes está contaminando os outros com o seu medo".

Às funçôes propostas por Bühler, Popper (1997) acrescenta uma quarta, a argumentativa, fundamental para a discussão da linguagem enquanto um instrumento de transferência de conhecimento.

Nenhum sistema de comunicação encontrado no reino animal se compara, no entanto, à linguagem humana, às funçóes simbólicas que são características da linguagem humana. Várias teorias atribuem a origem da linguagem humana a existência de uma protolinguagem (Nowak \& Komaronova, 2001). A partir de sons isolados - palavras - associados a significados numa relação um para um, a linguagem humana evoluiu, incorporando funçôes sintáticas (Chomsky, 2002), a serialização de palavras (Nowak \& Komaronova, 2001). Na linguagem humana significados não são somente dados por palavras isoladas, mas por combinaçôes de palavras. Desta forma podiam ser criadas possibilidades infinitas de combinaçôes e, consequentemente, de novos significados. Estes autores mostram como esta crescente flexibilização junto com o potencial comunicativo e a economia de energia proporcionada pela linguagem humana acabaram tornando-a um diferencial evolutivo decisivo.

A linguagem, como um primeiro grau de externalização do pensamento simbólico, permite maior cooperação e articulação social. Dunbar (1993) ao discutir a vida social dos primatas chama atenção para o tempo gasto nos contatos sociais necessários para manter a estabilidade e os vínculos do grupo: macacos passam grande parte do seu tempo coçando uns aos outros ou catando piolhos. Ao discutir os contatos sociais em grupos de humanos primitivos. Esse autor afirma que a possibilidade de grupos sociais maiores dependia de mecanismos mais eficientes de manter os contatos sociais indispensáveis à coesão do grupo e afirma que só a linguagem cumpria esta finalidade.

Com certeza uma mutação genética por si só não criou a linguagem, mas esta habilidade encontrou nos grupos sociais humanos cada vez mais complexos a possibilidade de desenvolver-se. As mutaçóes que viabilizaram a linguagem humana foram as últimas alteraçôes biológicas significativas na espécie humana. Somos hoje biologicamente idênticos aos nossos antepassados de 100.000 anos atrás. A partir deste período o grande vetor evolutivo da humanidade tem sido a cultura.

A linguagem é uma característica humana que é um pré-requisito para a evolução da cultura como nós a entendemos, uma cultura crescentemente acumulativa. Uma linguagem cada vez mais sofisticada no sentido de ser capaz de expressar pensamento simbólico, ou seja, capaz de contar, descrever, re-apresentar, socializar situaçóes na ausência delas, argumentar, convencer, se torna um forte mecanismo de cooperação e articulaçáo social e garante à espécie humana um diferencial evolutivo decisivo.

Num momento histórico mais recente, há cerca de 5.000 anos A.C., no contexto já de sociedades humanas bastante complexas, a linguagem falada é externalizada, 
fixada, têm superada sua fragilidade e perenidade como mecanismo de comunicaçáo intersubjetivo, materializada através de artefatos na escrita e desta no documento.

\section{Documento}

Pode-se considerar as construçôes em pedra encontrados em Stonehenge, na Inglaterra, como um dos primeiros monumentos da história humana. Quando relacionados com a escrita, o surgimento de estelas votivas relatando os feitos guerreiros de reis como as encontradas na Mesopotâmia e Egito, é mais ou menos contemporâneo ao surgimento das primeiras tábuas de barro com a escrita cuneiforme e dos primeiros papiros com hieróglifos. Le Goff (2003) faz uma distinção entre monumento e documento. Ambos pretendem perenizar uma mensagem. No entanto a diferença é que o documento, ao contrário do monumento, era e é hoje cada vez mais, portátil. Ao contrário do monumento, fixado, imóvel, o documento permite transferir uma mensagem não somente através do tempo, como o monumento, mas também (e cada vez mais) através do espaço. O documento, portanto, é um artefato sócio-técnico, artificial, uma descoberta tecnológica, correlata à descoberta da escrita, que permite viabilizar a intenção de seu criador de transferir mensagens através do tempo e do espaço.

Esta descoberta tecnológica, que provavelmente náo tem um criador único, abriu para a humanidade um enorme potencial de desenvolvimento social/cultural. Sociedades social e culturalmente cada vez mais complexas puderam se articular, cooperar, garantir a preservação da cultura e do conhecimento duramente adquirido pelas geraçóes anteriores, mediados por documentos. Neste sentido o documento guarda uma continuidade evolutiva e amplia as potencialidades da cultura, da linguagem e da escrita.

Documentos têm, primariamente, um caráter instrumental. As mensagens transferidas através de documentos têm a intenção genérica de informarem algo, ou seja, de alterarem o quadro mental de possíveis receptores, como postula Belkin (1976), um dos primeiros pensadores da Ciência da Informação que teorizaram sobre o conceito de informação. Através de sua função informativa documentos viabilizam, de forma mediada, a transferência de conhecimento, como é comumente discutido no contexto da Ciência da Informação. A visão do documento enquanto artefato informativo ou portador de informação, centrada em seu conteúdo como insumo de processos interpretativos, não dá conta, porém, de suas outras dimensões.

Como conseqüência e desdobramento de sua função informativa, que se dá em contexto sociais muito específicos, documentos têm uma função social-simbólica, normativa. Como é colocado por Briet $(2006,9)$ "A Document is a proof in support of a fact”. Documentos vêm sendo cada vez mais vistos (Brown \& Duguid, 1996), (Smith, 2005), (Frohmann, 2006) como instrumentos instaurados e instauradores de protocolos e relaçóes sociais. Uma infinidade de relaçóes sociais essenciais para o funcionamento de sociedades cada vez mais complexas ${ }^{2}$, regidas por relaçóes normativas

\footnotetext{
2 A Teoria Geral dos Sistemas considera as sociedades humanas como um dos exemplos de sistemas complexos. Ver Santaella (2008).
} 
em oposição às relações pessoais, características das sociedades mais primitivas, são mediadas por documentos. Barry Smith (2005) faz alusão ao texto de John Searle intitulado "Speech Acts"3 quando propóe uma teoria do que o autor chama de "document acts": “... it might be used to provide a better understanding of the role of documents in the coordination of human actions". As funçôes do documento de articulação, coordenação e cooperação social se aplicam também, naturalmente, à sociedade contemporânea.

Documentos também devem ser considerados como condicionados tecnologicamente. Evoluíram das tabuinhas de barro e dos papiros para os pergaminhos de pele, para os códices, para os documentos impressos até os documentos digitais da atualidade. Muita coisa mudou nestas diferentes tipos, mas também muita coisa permanece. Discussóes sobre a desmaterialização trazida pelos documentos digitais fazem pouco sentido. Documentos são unidades discretas de registro e transferência de mensagens; a aparente fluidez de limites dos documentos digitais hipertextuais, problemas de validade desses documentos, são decorrência do estágio tecnológico recente de desenvolvimento dos documentos digitais, que logo serão superados pelo desenvolvimento tecnológico. Um usuário concreto conhece muito bem as fronteiras dos documentos que usa. Devemos nos lembrar que estamos numa fase de transição entre uma sociedade que utiliza documentos em papel para uma que utiliza documentos digitais.

Documentos também têm um ciclo de vida, como já foi reconhecido há tempos pela Arquivística (Rousseu \& Couture, 1998). Ao cumprirem sua função primária de informarem e regularem relaçóes sociais, documentos podem vir a adquirir um caráter secundário, ao serem identificados como tendo valor de patrimônios culturais.

A questão da intencionalidade também é uma característica dos documentos, que são, como já colocado, artefatos artificiais, criados com a intenção de informar.

Este ponto também é essencial, já que, desde os tempos de Suzanne Briet (Buckland, 1991), nossa área discute o caráter documental de objetos, como o antílope de Briet, colocado numa coleção zoológica. No texto citado Buckland chega a conclusão que qualquer coisa pode ser informativa: "If anything is, or might be, informative, then everything is, or might well be, information."

Noçôes como informação, objeto informativo, ou objeto com potencial de informar, são portanto mais amplas que a de documento. Qualquer coisa, como coloca Buckland, pode ser informativa, a natureza em geral pode ser informativa, é plena de potencial informativo. A chave para compreendermos os processos informativos é dada pela Semiótica (Santaella, 2008). Vários autores (Raber \& Budd, 2003), (Brier, 2004), (Huang, 2006) têm buscado aportes da Semiótica para chegarem a definiçóes de informação. O criador da Semiótica moderna, Charles Sanders Pierce, citado por Santaella (2008, p. 62) afirma que:

O signo é qualquer coisa que é, de um lado, de tal modo é determinado por um objeto e, por outro lado, de tal modo determina uma idéia na mente de alguém que

\footnotetext{
${ }^{3}$ Searle, John R. (1969) Speech Acts: An Essay in the Philosophy of Language. Cambridge: Cambridge University Press.
} 
esta última determinação, chamada de interpretante do signo, é consequentemente determinada mediatamente por aquele objeto.

Um documento é, portanto, muito mais que somente um "portador de informações", limitado ao seu conteúdo intrínseco e a interpretação deste por um usuário, como colocado em algumas visôes iniciais da CI, aplicadas a contextos de transferência de textos científicos. Apesar da Semiótica trazer para a discussão da informação a questão da interpretaçáo, que normalmente esta associada a processos subjetivos, este grau de subjetividade dos processos interpretativos deve ser relativizado quando linguagem humana é usada para comunicar mensagens, funçáo para a qual ela tem sido extremamente efetiva. Quando nos primórdios da cultura humana nossos antepassados falavam de "comida", "perigo", "atração sexual", estas mensagens eram muito claras.

Isolar conteúdos e contextos sociais de produção e uso de documentos traz prejuízos para a interpretação desses conteúdos. A evolução das sociedades humanas mostra que os processos comunicativos que fazem uso da linguagem, aí incluso documentos, apesar de terem aspectos de subjetividade, quando vistos em seus contextos sociais de uso específicos, são bastante precisos quanto ao seu significado. É isso que permite que documentos funcionem como mecanismos de articulação, coordenação e cooperação social. A linguagem como mecanismo primordial neste sentido, só pode dar conta desse papel em sociedades cada vez maiores e mais complexas quando externalizada através de artefatos sócio-técnicos como documentos. As funçôes da linguagem (Bühler, 1990), (Popper, 1997) foram herdadas e ampliadas nos documentos.

Assim, qualquer coisa, objetos ou fenômenos, é informação, ou melhor, é informativa, quando esta inserida numa relação sígnica com um intérprete. A etimologia da palavra informação é bastante esclarecedora sobre seu significado. Segundo o Online Etymology Dictionary informação quer dizer: "1387, "act of informing," from O.Fr. informacion, from L. informationem (nom. informatio) "outline, concept, idea,» noun of action from informare (see inform)". Assim, informação, no contexto que possa interessar à CI, não é uma coisa, é um processo, o processo de interpretar fenômenos potencialmente informativos por um usuário.

Documentos, no entanto, são objetos especiais inseridos em relaçôes sígnicas, por serem artefatos, por serem artificiais, por carregarem uma intencionalidade. Significativamente, no esquema triádico de Pierce, o produtor/criador do signo e sua intencionalidade, não são mencionados. A intencionalidade no entanto, é básica para caracterizarmos documentos. Um antílope qualquer é informativo para um cientista, mas não é um documento. $\mathrm{O}$ antílope em condiçôes naturais pressupõe um determinado contexto. $\mathrm{O}$ antílope de Briet, ao passar por um processo de patrimonialização enquanto objeto de interesse da ciência e da cultura, ao qual foi agregado valor informativo ao ser re-contextualizado, quando esta re-contextualização é registrada com a intenção de informar, transforma-se num híbrido objeto cultural-documento. $\mathrm{O}$ trabalho intencional de um profissional de informação transforma um objeto em documento.

A intencionalidade portanto é fundamental, tanto para a caracterizaçáo de objeto potencialmente informativo como um documento, como para caracterizar o trabalho do profissional de informação. De uma certa forma sempre existiu e cada vez mais existe uma super-oferta de potencialidades informativas. Profissionais de informação e, pode-se dizer, sistemas de informação, trabalham com a intenção de maximizarem 
as oportunidades de interpretação de objetos com potencial informativo por parte de usuários. Esse potencial informativo é determinado por consenso, a partir da avaliação desse potencial informativo, como afirma Buckland (1991, p. 9). Para fazerem isso profissionais de informação criam signos - representaçóes de documentos ou de objetos com potencial informacional - e as organizam de forma sistêmica em dispositivos como catálogos, bases de dados, índices, etc. para viabilizar que usuários encontrem os recursos informacionais de seu interesse de forma otimizada. $\mathrm{O}$ trabalho com representaçóes obedece aos mesmos princípios econômicos que o pensamento simbólico e a linguagem: é muito mais vantajoso do ponto de vista de dispêndio de energia trabalhar com representaçóes que diretamente com a realidade; quando consultamos um mapa para nos orientarmos, quando usamos uma planta baixa para avaliarmos espaços num prédio, estamos trabalhando com representaçóes e nos valendo da economia de energia proporcionada por elas.

Representações, como uma referência bibliográfica inserida num dispositivo como um catálogo, permitem que usuários decidam confortavelmente sobre a relevância de documentos com um dispêndio de energia muito menor que se tivessem que consultá-los todos de maneira aleatória. Referências, enquanto signos de signos, signos de documentos, permitem a usuários realizar inferências sobre a relevâncias dos mesmos com um alto grau de certeza e decidirem se vale a pena despenderem energia extra para acessá-los, lê-los, etc. Na economia da informação (Marcondes, 2001) este é o valor que profissional de informação e sistemas de informação agregam com seus serviços e produtos.

$\mathrm{Na}$ visão apresentada, documentos são entidades sociais vivas, inseridos em redes sociais (Frohann, 1995) como um dos seus componentes essenciais, dos quais as sociedades contemporâneas lançam mão e dependem para viabilizarem coordenação, cooperação e articulação social. Cristalizam protocolos e relaçôes sociais de força, que os documentos, de alguma maneira, representam.

Pode-se formalizar estas noçóes acerca do documento como se segue:

Caráter instrumental - primário - dos documentos:

- Documentos são artefatos sócio-técnicos que se constituem em unidades discretas de registro e transferência mediada de mensagens - conjuntos de signos sistematizados.

- Documentos são produzidos a partir da intencionalidade de seu produtor, de transferir signos através do tempo e do espaço.

- A funçâo sígnica do documento é registrar fatos e atestar, portanto, sua ocorrência. Esta função se desdobra no seu conteúdo, na sua forma e no contexto social onde o documento funciona.

- As funções dos documentos acontecem dentro de contextos sociais bem definidos. Documentos são instaurados e instauram relaçóes sociais, são instituiçóes sociais, criados para um propósito específico.

- Documentos pressupóem um protocolo social ao qual eles atendem, um contexto de produção/produtor, um contexto de transferência e um contexto de uso/usuário.

- Caráter patrimonial - secundário - patrimonialização de objetos culturais, incluso documentos: 
- Documentos quando reconhecidos pelo seu valor enquanto objetos culturais - uma obra rara numa biblioteca, um documento arquivístico de valor histórico - ou quando agregados a outros objetos, documentando-os e complementando-os enquanto objetos culturais - num híbrido objeto cultural-documento -, como o antílope numa coleção zoológica ou um objeto museológico catalogado.

- Nestas situaçóes, documentos, pelo seu valor cultural, pelo seu caráter único ou por serem representativos de um conjunto, sacrificam sua portabilidade.

\section{Conclusôes}

Enquanto fenômenos culturais, entre os diferentes processos informativos, são de especial interesse para a Ciência da Informação aqueles que envolvem documentos. Ao permitir transferir mensagens através do espaço e do tempo a "invenção" do documento mantém, amplia e potencializa as funçóes de articulação, coordenação e cooperação social da linguagem. Mensagens externalizadas em documentos permitem perenizar a ocorrência de fatos, as experiências e o conhecimento e, desta maneira, reutilizálo. Documentos são um avanço tecnológico, uma ferramenta que, ao externalizar o conhecimento, permitiu armazená-lo, transferi-lo, cotejá-lo, atualizá-lo. Todas estas operaçóes sociais sobre o conhecimento registrado em documentos tem suas potencialidades expandidas com o aporte das tecnologias de informaçáo, permitindo assim sua apropriação social em larga escala, como é requerido pela sociedade atual.

Enquanto artefato sócio-técnico inserido na Cultura, o documento pressupoóe o processo informativo de documentar enquanto intencionalidade. A materialidade/ instrumentalidade do documento só é possível enquanto inserido em relaçôes sociais que o instauram e que são instauradas por ele. Separar estas múltiplas dimensōes é ter uma visão parcial e unilateral dos processos sociais envolvendo o documento.

A visão do documento como um artefato sócio-técnico introduz uma dimensão social que é essencial para compreensão o seu papel em nossa sociedade e em sociedades passadas. Um documento, visto como um artefato social, se refere, implícita e/ou explicitamente, a um conjunto de outros documentos e, implicitamente, a um conjunto de relações sociais sem os quais sua compreensão é incompleta. Os diferentes tipos de certificados de propriedade, de escrituras de imóveis, referem-se a ou pressupóe, implicitamente, todo um conjunto de leis que formalizam relaçôes sociais. Artigos científicos aceitos para publicação em periódicos significam pontos no sistema de retribuiçôes vigente na comunidade acadêmica. Documentos de identidade referemse a registros do cidadão numa instituição da administração pública e também a toda uma legislação.

O Documento é uma conquista tecnológica da humanidade que permitiu um novo patamar no desenvolvimento da cultura. Como instrumento e extensão da mente e da linguagem humanas, ele permite mediar o conhecimento adquirido, superar as fragilidades da memória e transferir conhecimento através do espaço e do tempo. É inquestionável o papel do conhecimento para o desenvolvimento da sociedade atual ou no, nas palavras de Castells (1999, p. 54): "modo informacional de desenvolvimento". Neste contexto a Ciência da Informaçáo interessa-se especialmente pelos processos de 
transferência de conhecimento mediados por documentos, de modo a permitir sua apropriação social em larga escala, como é requerido pela sociedade atual.

\section{Referências bibliográficas}

Bates, Marcia J. (2005). Information and knowledge: an evolutionary framework for Information Science. Information Research, 10(4), July. Disponível em http://informationr.net/ir/104/paper239.html. Acesso em 23 ago. 2005.

Belkin, Nicholas J.; Robertson, Stephen E. (1976). Information Science and the phenomenon of information. Journal of the American Society for Information Science, July-August.

Brier, Sören. (2004). Cybersemiotics and the problem of information processing paradigm as a candidate for a unified science of information behind library information science. Library Trends, 52(3), 629-658. Disponível em http://www.periodicos.capes.gov.br. Acesso em 1 ago. 2004.

Briet, Suzanne. (2006). What is Documentation? MD: Scarecrow press. Disponível em <http:// people.ischool.berkeley.edu/ buckland/briet.html>. Acesso em 24 de jul. 2009.

Brown, John Seely; Duguid, Paul. (1996). The Social Life of Documents. First Monday, 1(6), May 1996. Disponível em <http://firstmonday.org/htbin/cgiwrap/bin/ojs/index.php/fm/ article/view/466/820>. Acesso em 05 mar. 2009.

Buckland, Michael. (1991). Information as thing. Journal of the American Society of Information Science, 42(5) 351-360. Disponível em <http://www.sims.berkley.edu/ - buckland/thing. html>. Acesso em 9 nov. 2003.

Bühler, Karl. Theory of language: the representational function of language. (1990). Philadelphia/ Amsterdam: John Benjamin Publishing Company.

Castells, Manoel. (1999). A sociedade em rede. Vol. 1 - A era da informação: economia, sociedade e cultura. São Paulo: Paz e Terra.

Chomsky, Noam. (2002). Syntactic structures. 2nd. ed. Berlin, New York: Mouton de Gruyter.

Dunbar, R. I. M. (1993). Coevolution of neocortical size, group size and language in humans. Behavioral and Brain Sciences 16 (4), 681-735. Disponível em < http://www.bbsonline. org/documents/a/00/00/05/65/bbs00000565-00/bbs.dunbar.html?rel=nofollow $>$. Acesso em 14 julho 2009.

Freitas, Lídia Silva de. (2003). Sentidos da História e História dos sentidos da Ciência da Informaçáo. Morpheus, 2. Disponível em <http://www.unirio.br/morpheusonline/Numero022003/lidiafreitas.htm>. Acesso em 20 jul. 2009.

Frohmann, Bernd. (2006). O caráter social, material e público da informação na contemporaneidade. Palestra de abertura do VII ENANCIB, Marília/SP.

Frohmann, Bernd. Taking policy beyond information science: applying the actor network theory for connectedness: information, systems, people, organizations. In: Annual Conference of Canadian Association for Information Science, 23, 1995, Proceedings... Edmond, Alberta. Disponível em: <http://instruct.uwo.ca/faculty/Frohmann> Acesso em: 1 out. 2008.

Huang, Sheng-Cheng. (2006). A Semiotic View of Information: Semiotics as a Foundation of LIS Research in Information Behavior. In Grove, Andrew, Eds. Annual Meeting of the American Society for Information Science and Technology (ASIST) 43, Proceedings... Austin (US). Disponivel em <http://eprints.rclis.org/archive/00008436/01/Huang_Semiotic. pdf>. Acesso em 4 nov. 2008. 
Introduction. In: Carreuthers, Peter; Chamberlain, Andrew, (eds.). (2003). Evolution and the human mind: modularity, language and meta-cognition. Cambridge (UK): Cambridge University Press. Disponível em <http://catdir.loc.gov/catdir/samples/cam033/00021834. pdf>. Acesso em 13 fev. 2009.

Knight, Chris; Studdert-Kennedy, Michael; Hurford, James R. (2000). Language: a Darwinian adaptation? In: Knight, Chris; Studdert-Kennedy, Michael; Hurford, James R. (eds.). The evolutionary emergence of language: social functions and the origins of linguistic form. Cambridge: Cambridge University Press. Disponível em <http://catdir.loc.gov/catdir/ samples/cam031/00020471.pdf>. Acesso em 13 fev. 2009.

Le Goff, Jacques. (2003). Documento/Monumento. In: História e Memória. (pp. 525-541). Campinas: Ed. Unicamp.

Lund, Niels Windfeld. (2009). Document theory. In: Croni, Blaise (ed.). Annual Review of Information Science and Technology. (pp. 399-432). Silver Spring, MD, EUA: ASIS\&T; Meford, NJ, EUA: Information Today.

MARCONDES, Carlos Henrique. (2001). Representação e economia da informação. Ciência da Informação, 30(1), 61-70. Disponível em http://www.scielo.br/scielo.php?script=sci_ arttext\&pid=S0100-19652001000100008\&lng=en\&nrm=iso.

Maturana, Humberto R., Varela, Francisco J. (2001). A árvore do conhecimento: as bases biológicas da compreensão humana. São Paulo: Palas Athena.

Nowak, Martin; Komarova, Natalia L. (2001). Towards an evolutionary theory of language. TRENDS in Cognitive Sciences, 5(7), 288-295.

ONLINE Ethimology Dictionary. Disponível em < http://www.etymonline.com/>. Acesso em 23 jul. 2009.

Popper, Karl. (1997). El cuerpo y la mente. Barcelona: Paidós.

Raber, Douglas; Budd, John M. (2003). Information as sign: semiotics and information Science. Journal of Documentation, 59(5), 507-522. Disponível em http://www.periodicos.capes.gov. br. Acesso em 15 ago. 2004.

Rousseu, Jean_Yves; Couture, Carol. Os fundamentos da disciplina arquivistica. (1998). Lisboa: Publicaçôes Dom Quixote.

Shera, Jesse H.; Cleveland, Donald B. (1977). History and foundations of Information Science. Annual Review of Information Science and Technology, 12, 249-275.

Smith, Barry. Document Acts. [s.1.],[2005]. Disponível em <http://ontology.buffalo.edu/ document_ontology/document_acts.doc>. Acesso em 20 mar. 2007.

Tattersall, Yan. Como nos tornamos humanos. Scientific American Brasil Edição especial, 17.

Vygotsky, Lev Semenovitch. (2001). Pensamento e linguagem. Ebooks.com. Disponível em $<$ <ttp://www.ebooksbrasil.org/adobeebook/vigo.pdf>. Acesso 11 jul. 2009.

Wong, Kate. O despertar da mente humana. Scientific American Brasil Edição especial n. 17.

Zins, Chain. (2006). Conceptual Approaches for Defining Data, Information, and Knowledge. Journal of the American Society for Information Science and Technology, 58(4):479-493. 